\title{
Cabergoline in severe ectopic or occult Cushing's syndrome
}

\section{Mirela Diana Iliee,2, Véronique Raverot ${ }^{3}$, François Tronc ${ }^{2,4}$, Alexandre Vasiljevic ${ }^{2,5}$, Françoise Borson-Chazot ${ }^{1,2}$ and Gérald Raverot ${ }^{1,2}$}

'Endocrinology Department, 'Groupement Hospitalier Est' Hospices Civils de Lyon, Lyon, France, ${ }^{2}$ Lyon 1 University, Lyon, France, ${ }^{3}$ Biochemistry Laboratory Department, ${ }^{4}$ Thoracic Surgery Department, and ${ }^{5}$ Department of Pathology, 'Groupement Hospitalier Est' Hospices Civils de Lyon, Lyon, France
Correspondence

should be addressed

to G Raverot

Email

gerald.raverot@chu-lyon.fr

\begin{abstract}
Context: Cabergoline has been shown to have some effect in the treatment of moderate Cushing's disease, but its effectiveness in Cushing's syndrome of ectopic or occult origin remains to be investigated.

Case series: In this case series, cabergoline was used in combination with steroidogenesis inhibitors in nine patients with severe Cushing's syndrome of ectopic or occult origin. Cabergoline's effectiveness enabled rapid withdrawal of the steroidogenesis inhibitors and long-term control of the hypercortisolism in three of the cases.

Review of the literature: In the literature, we found only 11 cases of ectopic or occult Cushing's syndrome treated with dopamine receptor agonists, alone or in combination. Yet of these 11 cases, 10 responded.

Conclusions: Although limited, the existing experience highlights the potential value of cabergoline in the treatment of ectopic or occult Cushing's syndrome.

\section{Introduction}

Cushing's syndrome (CS) is a rare but severe endocrine condition caused by chronic excess cortisol, resulting in debilitating morbidity and increased mortality $(1,2)$. It can be either adrenocorticotropic hormone (ACTH) dependent (70-80\% of cases) or ACTH independent (20$30 \%$ of cases). Among ACTH-dependent CS etiologies, Cushing's disease (CD) accounts for $80-90 \%$ of cases, ectopic ACTH secretion (EAS) for $10-20 \%$ of cases, and excessive corticotropin-releasing hormone (CRH) secretion is very rare (2).

The recommended first-line treatment in most cases is surgical removal of the tumor responsible for the hypersecretion. However, a differential diagnosis is not always straightforward and the origin of the hypercortisolism may remain occult, even for years. Furthermore, surgery may prove ineffective, not feasible or must be delayed. Therefore, second-line therapeutic options are sometimes needed $(3,4,5,6)$.
Cabergoline, a dopamine receptor agonist, has already proven to have some effect in the treatment of $\mathrm{CD}(3,6,7)$, with most papers reporting a $20-40 \%$ response rate (6). In terms of the effectiveness of cabergoline in EAS or occult CS, its use has been reported only in a few isolated case reports $(8,9,10,11,12,13)$ and in one prospective study limited to three patients and with a short follow-up (14). All of these studies support the potential effectiveness of cabergoline. Here, we report a nine case series of severe ectopic or occult CS treated with cabergoline.

\section{Patients and methods}

In this study, we describe the effect of cabergoline treatment in four severe ectopic cases and five severe occult cases of CS, first referred to our department between 2010 and 2017. Data were collected retrospectively from

Published by Bioscientifica Ltd. 
the patient's medical records. All hormonal assays were performed with commercially available kits. The study was in accordance with the Ethics Committee of Hospices Civils de Lyon. Informed consent has been obtained from the patients for publication of the case reports and accompanying images.

\section{Case reports}

\section{Case 1}

A 62-year-old female was referred to our department in July 2017 soon after the discovery of severe ACTH-dependent CS. She had as complications severe osteoporosis, diabetes (glycated hemoglobin $\left(\mathrm{HbA}_{1 \mathrm{c}}\right.$ ) 9.7\%), deep vein thrombosis, severe hypokalemia, amyotrophy and elbow and thigh epidermo-dermatitis. Laboratory findings are shown in Table 1.

Ketoconazole (400 mg twice daily) and cabergoline ( $0.5 \mathrm{mg}$ daily) were first administered and enabled the normalization of urinary free cortisol (UFC) and morning plasma cortisol and ACTH after 3 days. Ketoconazole was reduced in dose (to $200 \mathrm{mg}$ twice daily) 7 days after its introduction and stopped 3 days later. As laboratory results were suggestive of adrenal insufficiency, hydrocortisone supplementation (15-20 mg daily) was introduced 3 days after ketoconazole was stopped and was maintained for 2 months. Under cabergoline monotherapy, there was a marked and long-lasting clinical and biological improvement. Most notably, normal morning plasma ACTH, normal UFC (or slightly elevated UFC when daily hydrocortisone was administered) (Fig. 1A), normal kalemia, glucose metabolism and arterial blood pressure and improved muscular strength and reduced skin fragility.

Simultaneously with starting the treatment, the search for the etiology of this ACTH-dependent CS began. The pituitary MRI did not identify any pituitary mass. The chest CT revealed a $3 \mathrm{~cm}$ mass of the inferior lobe of the left lung with suspected pleural extension, but no evidence of metastases on the thoraco-abdominopelvic or cerebral CT. ${ }^{18} \mathrm{~F}$-FDG PET/CT showed moderate uptake by the pulmonary mass, whereas ${ }^{68} \mathrm{Ga}$-DOTA-TOC PET/ CT did not show any uptake (Fig. 2A, B and C). The hypercortisolism being extremely severe, we did not perform any dynamic testing in order to not delay the start of the treatment. Since the pulmonary mass was found, the clinical evolution was consistent with an EAS, and the hypercortisolism was well controlled on cabergoline, we did not perform an inferior petrosal sinus sampling either. The patient underwent left lower videothoracoscopic lobectomy with lobar-hilar and mediastinal lymph node dissection in January 2018. The pathological examination identified a typical carcinoid tumor measuring $2.4 \times 2.2 \times 2 \mathrm{~cm}$, pT1c NO R0, stage IA3. Fifteen per cent of the tumor cells stained positively for ACTH (Fig. 2D). Cabergoline was stopped 5 days after surgery. The hormonal assessment over the following 3 days showed normal UFC of $37 \mathrm{nmol} / 24 \mathrm{~h}(\mathrm{~N}<180)$, morning plasma ACTH of 10 and 11ng/L (N 7-63) and midnight plasma cortisol of $40 \mathrm{nmol} / \mathrm{L}$. The patient was still in remission in March 2019 (normal UFC of $60 \mathrm{nmol} / 24 \mathrm{~h}(\mathrm{~N}<138)$ and morning cortisol of $29 \mathrm{nmol} / \mathrm{L}$ after the $1 \mathrm{mg}$ overnight dexamethasone suppression test).

\section{Case 2}

A female aged 50 years at diagnosis of CS in 2010 was referred to our department in 2013. She did not have any notable past medical history. From diagnosis until 2013, she had a mild and cyclic but progressive hypercortisolism that remained untreated until October 2013 and led to hypertension, hypokalemia, osteopenia and prediabetes. Laboratory findings at that time are shown in Table 1.

The pituitary MRI did not identify any pituitary mass. Repeated imaging studies from 2010 to 2018 (thoracoabdominopelvic CT scan, pancreatic MRI, endoscopic ultrasound, ${ }^{18} \mathrm{~F}$-DOPA PET/CT and ${ }^{68} \mathrm{Ga}$-DOTA-TOC PET/ CT) found only asymmetric bilateral adrenal hyperplasia and an intraductal papillary mucinous tumor of the pancreas. The desmopressin test did not show significant stimulation, suggesting EAS (the plasma ACTH increased by only $25 \%$ and the serum cortisol decreased). Inferior petrosal sinus sampling was performed in 2012 but failed because of an anatomic variant. The etiology remains occult to this day.

Pasireotide (600 $\mu$ g twice daily) was started first, but during the 3 months on this treatment, control of the hypercortisolism was insufficient, secondary diabetes mellitus (HbA1c 8.9\%) occurred and the patient presented with abdominal complaints and experienced difficulties with daily injections. Ketoconazole ( $600 \mathrm{mg}$ daily) was then tried, but this treatment was stopped after 10 days because of hepatotoxicity. The next treatment, metyrapone, was continued for almost 2 years, from March 2014 to December 2015. Due to the escape of hypercortisolism from suppression, the dose of metyrapone was increased first (after 2 months) from $500 \mathrm{mg}$ three times daily to $750 \mathrm{mg}$ three times daily, and then (in January 2015) the 


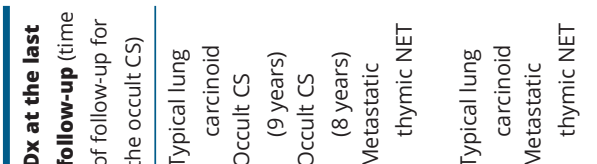

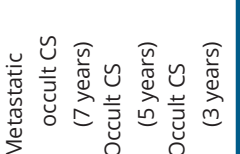

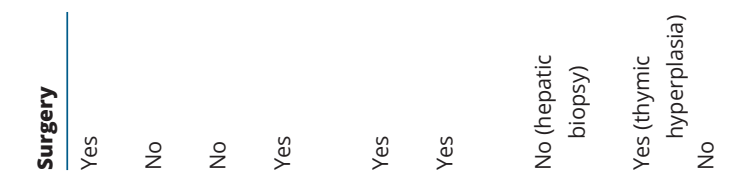<smiles>CCI</smiles>

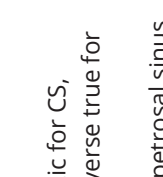

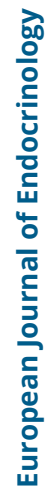

1

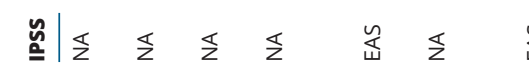

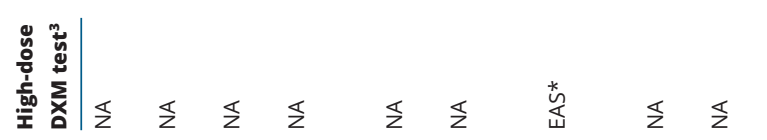

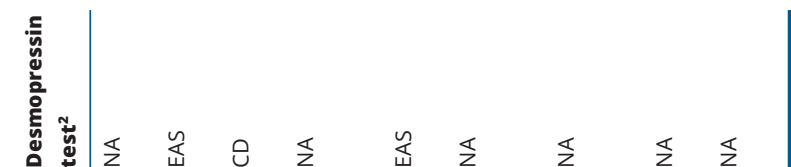

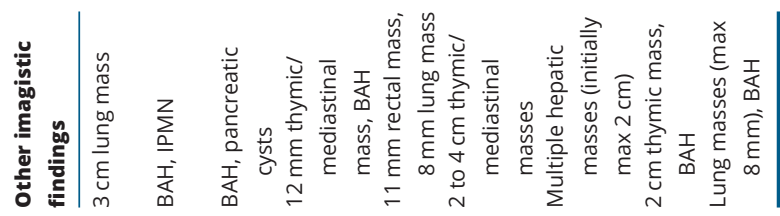

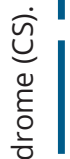

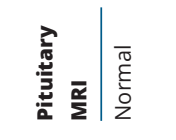

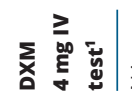

$\frac{2}{10}$

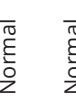

蛋

嚆

$\stackrel{1}{2}$

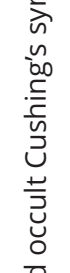

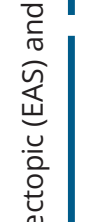

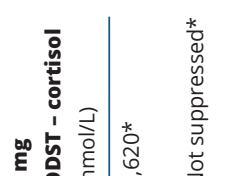

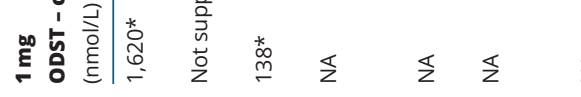

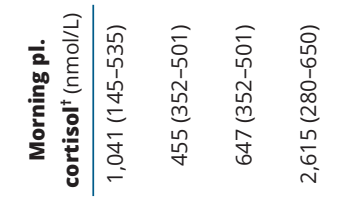

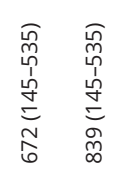

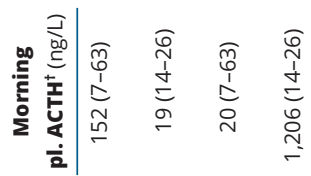

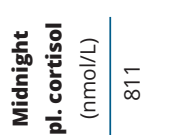

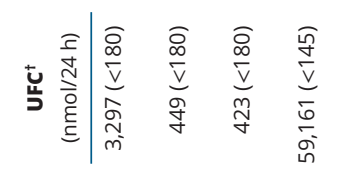

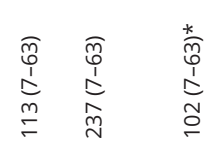

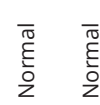

舀

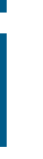

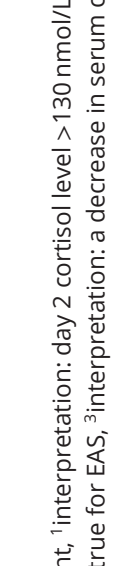

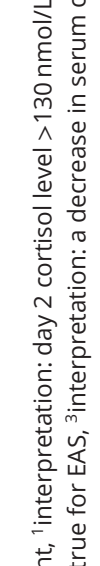

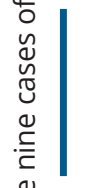

章

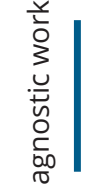

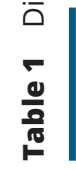

y $\frac{s}{2}$

y $\leftleftarrows$

$\Sigma \quad \Sigma \quad \stackrel{i}{\substack{0 \\ j}}$

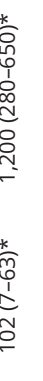

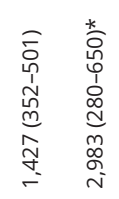

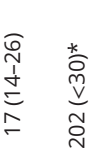

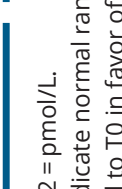

ㅇํㅅ

$\subseteq \longdiv { 0 }$

范皆

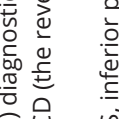

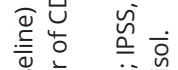

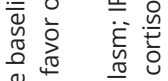

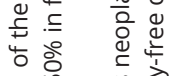

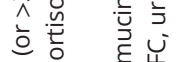

突它

$\frac{\pi}{2} \frac{\pi}{2}$

艺这

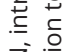

$\sum_{a}$

这 亭

它

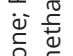

焉

竞

$\sum_{x}^{\infty}$

is

产 1 in

总

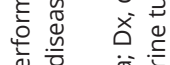

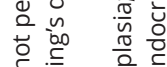

政

离㟧

$\frac{\pi}{\frac{\pi}{2}} \frac{\pi}{\frac{0}{0}}$

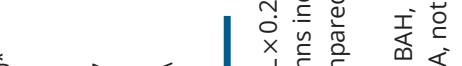

है

을

능 i⿱宀

일 
A
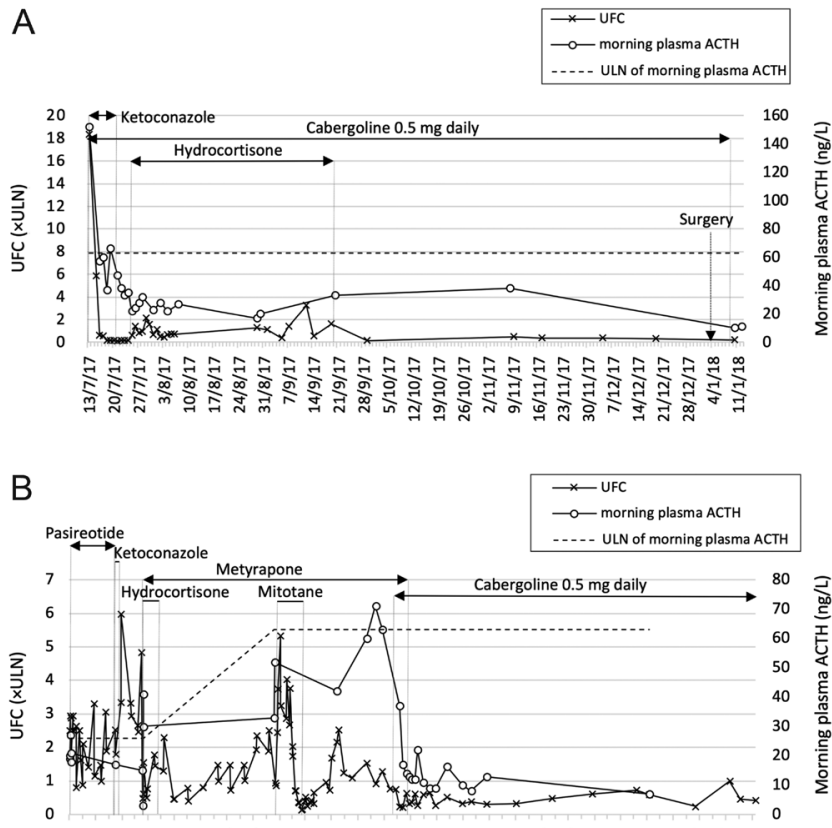

C

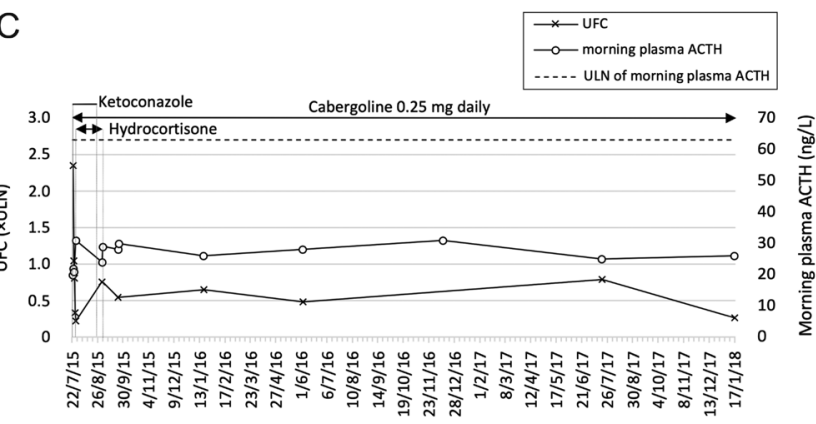

Figure 1

Levels of urinary-free cortisol (UFC) and morning plasma adrenocorticotropic hormone (ACTH) during treatment for Cushing's syndrome. Data are shown for case $1(A)$, case $2(B)$ and case 3 (C). The UFC is expressed in times the upper limit of the normal range (ULN), while the plasma ACTH is expressed in $\mathrm{ng} / \mathrm{L}$ (conversion factor: $\mathrm{ng} / \mathrm{L} \times 0.22=\mathrm{pmol} / \mathrm{L}$ ). Every dot represents an individual measurement.

dose was increased further to $1000 \mathrm{mg}$ three times daily and mitotane was added at a starting dose of $500 \mathrm{mg}$ three times daily. Mitotane was stopped after 2 months because of hepatotoxicity and dyslipidemia, and metyrapone was subsequently increased to $3750 \mathrm{mg}$ daily and bilateral adrenalectomy was proposed. In a final attempt to avoid adrenalectomy, cabergoline $(0.5 \mathrm{mg}$ daily) was used in addition to the metyrapone ( $3750 \mathrm{mg}$ daily) in November 2015 , and this enabled progressive diminution of the dose of metyrapone, which was stopped after 40 days. Since

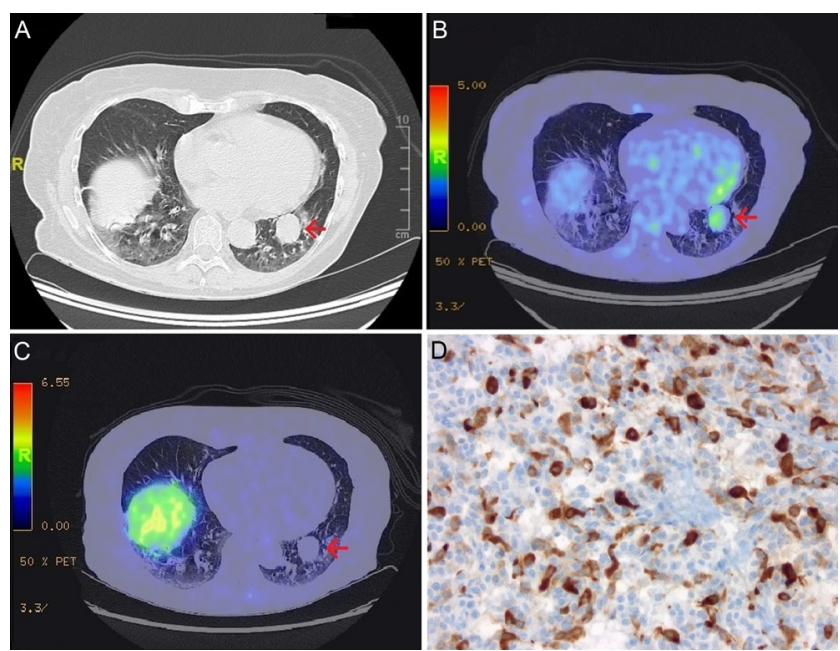

Figure 2

Radiological and immunohistochemical images for case 1. The left pulmonary mass is indicated by a red arrow, as seen on the CT scan (A). Moderate uptake of tracer by the pulmonary mass is shown on the ${ }^{18} \mathrm{~F}$-FDG PET/CT image (B), whereas the ${ }^{68} \mathrm{Ga}$-DOTATOC PET/CT image shows no uptake of the radiolabeled somatostatin analog by the pulmonary mass (C). Cytoplasmic immunoexpression of ACTH is observed in 15\% of neoplastic cells (original magnification, $\times 200$ ) (D).

December 2015, the patient has received only cabergoline (0.5 mg daily) and has shown normal UFC and plasma ACTH (Fig. 1B), improvement of hypercortisolism-related complications and no clinical signs of hypercortisolism.

\section{Case 3}

A male aged 71 years with notable past medical history of severe acute pancreatitis (in 2004, requiring pancreatic surgery) and coronary and cerebrovascular disease, was followed in our department from 2015. The patient presented with hypertension, dyslipidemia, diabetes, severe osteoporosis, amyotrophy and episodes of hypokalemia. Laboratory findings at that time are shown in Table 1.

The pituitary MRI did not identify any pituitary mass. The desmopressin test showed significant stimulation, suggesting $\mathrm{CD}$ (the plasma ACTH increased by $168 \%$ and the serum cortisol by $70 \%)$. Inferior petrosal sinus sampling was refused by the patient. Repeated imaging studies (pituitary MRI, thoraco-abdominopelvic CT scan, pancreatic MRI, endoscopic ultrasound, gastroscopy and ${ }^{18}$ F-FDG PET/CT) found nothing but asymmetric bilateral adrenal hyperplasia and pancreatic cysts (interpreted 
either as intraductal papillary mucinous tumors of the pancreas or as sequelae of the severe acute pancreatitis). The etiology remains occult to this day.

In July 2015, a treatment including ketoconazole (200 mg twice daily, then 2 days later, $400 \mathrm{mg}$ twice daily) and cabergoline $(0.25 \mathrm{mg}$ daily) was started. Under this treatment, UFC normalized in 2 days. Ketoconazole was stopped after 1 month because of hepatotoxicity and abdominal complaints. As the UFC remained normal, cabergoline was continued as a monotherapy (at the same dose, of $0.25 \mathrm{mg}$ daily) from August 2015. Under this treatment the patient had normal UFC (Fig. 1C) and a reduction in the clinical signs of hypercortisolism and hypercortisolism-related complications. Most notably, amyotrophy regressed, with a net functional improvement, and the metabolic syndrome improved.

\section{Cases 4-9}

Six more patients, three that proved to have EAS (two metastatic thymic neuroendocrine tumors (NETs) and one typical lung carcinoid), and three with occult CS, were treated with cabergoline in combination with steroidogenesis inhibitors. The initial laboratory findings and the differential diagnosis of the ACTH-dependent CS are presented in Table 1.

In these cases, cabergoline was started at a median daily dose of $0.5 \mathrm{mg}$ (range $0.25-1 \mathrm{mg}$ ), in combination with either ketoconazole (800-1200mg daily) or metyrapone (1500-3000 mg daily). In three of the cases (cases 7-9), the daily dose of cabergoline was increased after 8,5 and 4 days, respectively, to either $0.5 \mathrm{mg}$ daily or to $1 \mathrm{mg}$ daily. In one of the cases (case 9), this increase was only transitory (for 4 days) because of nausea. The median duration of cabergoline treatment for these 6 patients was 27 days (range 16-123 days). Cabergoline failed to normalize the ACTH in five of the six cases, while in case 8 , as the effectiveness of cabergoline was difficult to judge based on the evolution of ACTH (ACTH was frankly elevated only once before cabergoline was started), its administration was stopped because of very variable control of the UFC.

\section{Discussion}

Dopamine receptors (DRs) are widely distributed in the body, but particularly in normal and tumoral anterior pituitary (in both lactotroph and non-lactotroph cells), in other normal and tumoral neuroendocrine tissues (such as pheochromocytomas, paragangliomas, gastroenteropancreatic NETs, lung and thymic carcinoids), and normal and tumoral adrenal cortex $(7,14,15)$. In a study that included six carcinoid tumors responsible for EAS (one thymic and one pancreatic tumor and four lung tumors) (14), immunohistochemistry revealed that type 2 dopamine receptors (D2Rs) were expressed in five of the six tumors. Another study that examined D2R expression in 46 NETs of different sites found expression in $85 \%$ of cases and in all three cases that presented with EAS (16). Not only do NETs express DRs, but in vitro and in vivo studies have shown that dopamine receptor agonists acting on D2R, such as cabergoline and bromocriptine, are able to control cell proliferation and hormone secretion of NETs (15).

The idea of using dopamine receptor agonists in the treatment of ectopic or occult CS is not new; yet, there are very few publications on this subject. Of the 11 cases in the literature of ectopic or occult CS treated with dopamine receptor agonists alone or in combination $(8,9,10,11,12$, $13,14,17,18$ ) (Table 2), six had proven to be EAS before the dopamine receptor agonist was started, and four more proved to be EAS by the end of follow-up, only one remaining an occult CS. Eight of the ten cases of EAS were lung or bronchial carcinoids, which are the most frequent cause of EAS $(5,14)$. Of the 11 cases, bromocriptine was used in two cases, cabergoline in eight cases and in one case both cabergoline and bromocriptine were used. The median weekly dose of cabergoline was $3.5 \mathrm{mg}$ (range $0.5 \mathrm{mg}$ to $7 \mathrm{mg}$ ). In the one case (10) where low doses of cabergoline were administered, cabergoline was initiated at a dose of $0.5 \mathrm{mg}$ three times a week, and then a dose of $0.5 \mathrm{mg}$ weekly was given. In six cases, cabergoline was administered daily, while in the two remaining cases $(9,11)$, this information was not available. Similar to our cases, most of the 11 cases were of severe CS and dopamine receptor agonists were found to be effective in the treatment of both ectopic and occult CS. In one case (9), cabergoline was used with good results years after a bilateral adrenalectomy to control high levels of plasma ACTH, accompanied by intense skin hyperpigmentation. In the only prospective clinical study (14), Pivonello et al. administered cabergoline as a monotherapy at a starting dose of $0.5 \mathrm{mg}$ daily to three patients with EAS attributable to a lung carcinoid tumor and observed a normalization of plasma ACTH and UFC after 3 months in two of the three cases. The remaining patient was considered to be a nonresponder to cabergoline treatment after only 1 month. One of the two responsive patients showed an increase in plasma ACTH at 4 months and of UFC at 5 months 
Table 2 Previously reported cases of ectopic or occult Cushing's syndrome treated with dopamine receptor agonists.

$\frac{\text { Ref. }}{\text { (13) }} \frac{\begin{array}{c}\text { Findings before medical } \\ \text { treatment }\end{array}}{\begin{array}{c}65 \text { years, female, occult } \\ \text { Cushing's syndrome }\end{array}} \frac{\mathrm{UFC, \mu g/24 \textrm {h }}}{1,099} \frac{\mathrm{ACTH}, \mathrm{pg} / \mathrm{mL}}{225}$

(18)

23 years, female,
bronchial carcinoid
bronchial carcinoid

(17) 55 years, female, typical $>2,000$ lung carcinoid and tumorlets

(12)

45 years, female, neuroendocrine tumor of sphenoidal sinus

(10) 65 years, female, typical Not known lung carcinoid

\section{5 years, male, atypical $\sim 900$} lung carcinoid sex not known sex not known sex not known
Medical treatment (type, duration, effectiveness of the dopamine receptor agonist, escape from suppression by the dopamine receptor agonist)

1. Cabergoline $0.25-0.5 \mathrm{mg}$ daily for 40 days: plasma ACTH and cortisol at lower normal range for 40 days with no escape, then maintained normal for more than 1 year after the interruption of cabergoline

2. Relapse after 16 months leading to short-term treatment with cabergoline: normalized plasma ACTH and cortisol, maintained at normal levels for 1 year after the interruption of cabergoline

3. Relapse after 1 year leading to bromocriptine $2.5 \mathrm{mg} 2$ times per week, followed by $2.5 \mathrm{mg} 3$ times per week + hydrocortisone replacement (5-10 mg daily) for $\sim 46$ weeks: plasma ACTH and cortisol controlled within normal limits for almost 1 year with no escape

1. Cyproheptadine $8-32 \mathrm{mg}$ daily for $\sim 3$ months

2. Cyproheptadine $16 \mathrm{mg}$ daily + bromocriptine $5 \mathrm{mg}$ daily for $\sim 3$ months

3. Cyproheptadine $24 \mathrm{mg}$ daily + bromocriptine $10 \mathrm{mg}$ daily for 3 months: normalization of UFC in 1 month with no escape

1. Bromocriptine $7.5 \mathrm{mg}$, cyproheptadine $12 \mathrm{mg}$ and spironolactone $200 \mathrm{mg}$ daily for 2 months: normalization of the hormonal tests after 1 month with no escape

2. Bromocriptine alone ( $5 \mathrm{mg}$ daily) for 4 years and 2 months*: the 6-month follow-up showed sustained normal adrenal function for 4 years and 2 months with an escape after 4 years and 4 months

Cabergoline $0.5 \mathrm{mg}$ daily for 9 months: UFC and midnight salivary cortisol levels decreased significantly within 2-3 months, accompanied by normalization of blood pressure and menses; midnight salivary cortisol levels normalized after 6 months and UFC normalized after 8 months. No escape

Not known 1. Octreotide $0.05 \mathrm{mg} / 8 \mathrm{~h}$ and cabergoline $0.5 \mathrm{mg} 3$ times/week*: in 2 weeks, cortisol, ACTH, UFC levels, glycemia and potassium normalized; both treatments withdrawn because of severe urticaria

2. Cabergoline $0.5 \mathrm{mg} /$ week: restoration of normal cortisol levels with no escape

1. Lanreotide $90 \mathrm{mg} / \mathrm{month}$ for 1 year

2. Cabergoline $7 \mathrm{mg}$ /week for 1 year: after 6 months of cabergoline, ACTH and cortisol secretion normalized. Escape after 1 year.

3. Lanreotide was added to cabergoline, resulting in rapid normalization of plasma ACTH and UFC, which remained normal for the rest of the follow-up period

$\sim 140 \mathrm{ng} / \mathrm{L} \quad$ Cabergoline $0.5 \mathrm{mg}$ daily for 6 months: significant inhibition of plasma ACTH, as well as serum and urinary cortisol levels after 1 month. Complete normalization of both ACTH and cortisol levels after 3 months, and significant clinical improvement. No escape

$\sim 125 \mathrm{ng} / \mathrm{L} \quad$ Cabergoline $0.5 \mathrm{mg}$ daily, then $1 \mathrm{mg}$ daily for a total duration of 6 months: significant inhibition of plasma ACTH, as well as serum and urinary cortisol levels after 1 month. Complete normalization of both ACTH and cortisol levels after 3 months, and significant clinical improvement. ACTH started to rise again at 4 months and UFC at 5 months, and these did not normalize despite augmentation of the cabergoline dose

$\sim 160 \mathrm{ng} / \mathrm{L} \quad$ Cabergoline $0.5 \mathrm{mg}$ daily for $1 \mathrm{month}$, without effect 
Table 2 Continued.

\begin{tabular}{|c|c|c|c|c|}
\hline \multirow[b]{2}{*}{ Ref. } & \multirow[b]{2}{*}{ Age, sex, diagnosis } & \multicolumn{2}{|c|}{$\begin{array}{l}\text { Findings before medical } \\
\text { treatment }\end{array}$} & \multirow{2}{*}{$\begin{array}{l}\text { Medical treatment (type, duration, effectiveness of the dopamine receptor } \\
\text { agonist, escape from suppression by the dopamine receptor agonist) }\end{array}$} \\
\hline & & $\mathrm{UFC}, \mu \mathrm{g} / 24 \mathrm{~h}$ & ACTH, pg/mL & \\
\hline (8) & $\begin{array}{l}15 \text { years, female, Ewing } \\
\text { sarcoma }\end{array}$ & $10,365 \mathrm{nmol} / \mathrm{L}$ & $437 \mathrm{pmol} / \mathrm{L}$ & $\begin{array}{l}\text { 1. Cabergoline } 0.5 \mathrm{mg} \text { daily for } 1 \text { month + neoadjuvant } \\
\text { chemotherapy started } 24 \mathrm{~h} \text { later: normalization of blood } \\
\text { pressure } 3 \text { days after initiation of cabergoline. Serum cortisol } \\
\text { decreased from } 2,244 \text { to } 306 \mu \mathrm{g} / \mathrm{L} \text { within } 10 \text { days. At the end of } \\
\text { cabergoline therapy, serum ACTH was normal and remained } \\
\text { normal } 1 \text { month after cabergoline cessation. No escape. } \\
\text { 2. Chemotherapy }\end{array}$ \\
\hline \multirow[t]{2}{*}{ (9) } & $\begin{array}{l}40 \text { years, female, lung } \\
\text { carcinoid }\end{array}$ & 40 & 34 & $\begin{array}{l}\text { 1. Ketoconazole } 800 \mathrm{mg} \text { and aminoglutethimide } 1,500 \mathrm{mg} \text { daily } \\
\text { 2. Bilateral adrenalectomy } \\
\text { 3. Octreotide } 20 \mathrm{mg} \text { monthly for } 3 \text { years }\end{array}$ \\
\hline & & & & $\begin{array}{l}\text { 4. Cabergoline } 3.5 \mathrm{mg} \text { weekly for } 10 \text { years*: under cabergoline, } \\
\text { the plasma ACTH decreased from greater than } 1,250 \mathrm{pg} / \mathrm{mL} \\
\text { to } 806 \mathrm{pg} / \mathrm{mL} \text { at } 30 \text { days, } 244 \mathrm{pg} / \mathrm{mL} \text { at } 8 \text { months and } 149 \mathrm{pg} / \\
\mathrm{mL} \text { at } 14 \text { months, accompanied by a marked reduction in skin } \\
\text { pigmentation. No escape }\end{array}$ \\
\hline
\end{tabular}

Conversion factor: plasma ACTH: $\mathrm{pg} / \mathrm{mL} \times 0.22=\mathrm{pmol} / \mathrm{L}$ and $\mathrm{ng} / \mathrm{L} \times 0.22=\mathrm{pmol} / \mathrm{L} ; \mathrm{UFC}: \mu \mathrm{g} / 24 \mathrm{~h} \times 2.76=\mathrm{nmol} / 24 \mathrm{~h}$ and $\mu \mathrm{gg} / \mathrm{L} \times 2.76=\mathrm{nmol} / \mathrm{L} ;$ serum cortisol: $\mu \mathrm{g} / \mathrm{L} \times 2.76=\mathrm{nmol} / \mathrm{L}$.

*In these three cases, treatment was transiently withdrawn resulting in an increase in the cortisol and/or the ACTH levels; the increase was controlled by reinstating the treatment.

ACTH, adrenocorticotropic hormone; Ref., reference; UFC, urinary free cortisol.

of treatment. Cabergoline was therefore increased to $1 \mathrm{mg}$ daily but the hypercortisolism was still not under control at the 6-month follow-up, so cabergoline treatment was discontinued rapidly. For the patient with sustained control of the hypercortisolism at the 6-month follow-up, no further data were available beyond this point (14). In terms of side effects, mild drowsiness was reported in one patient receiving bromocriptine (18), and initial fatigue in one patient receiving cabergoline (12). No side effects were noted in another patient receiving cabergoline (10), while the presence or absence of side effects was not mentioned in the remaining eight cases.

In our three patients that responded, cabergoline ( 0.25 or $0.5 \mathrm{mg}$ daily) was started in addition to steroidogenesis inhibitors. We chose this starting dose based on the literature and maintained it because it was effective and well tolerated. In all three patients, cabergoline permitted the rapid withdrawal of steroidogenesis inhibitors after 10-40 days. In the first case, the UFC was initially 18 times the upper limit of normal (ULN), and in the second case, hypercortisolism was not controlled by $3750 \mathrm{mg}$ of metyrapone daily, nor by pasireotide, and the patient had not tolerated other treatments well (pasireotide, ketoconazole and mitotane). Under cabergoline, all three patients experienced significant improvement in the clinical signs of hypercortisolism and hypercortisolismrelated complications and had long-lasting control of the hypercortisolism, with no escape. The tolerability and effectiveness of the treatment were maintained until the last follow-up or until the surgical cure in the case of proven EAS (the duration of follow-up under cabergoline for cases 1, 2 and 3 were 5, 27 and 29 months, respectively).

Despite the impressive results in these three cases, the response to cabergoline is not constant. Indeed, in six other patients with severe hypercortisolism (two with metastatic thymic NETs, one with a lung carcinoid tumor and three of occult origin) treated during the same period of time, adding cabergoline to the steroidogenesis inhibitors was not effective. The starting dose in these cases was $0.25-1 \mathrm{mg}$ daily, and the final dose was $0.5 \mathrm{mg}$ to $1 \mathrm{mg}$ daily. Rapidly (after $4-8$ days) increasing the daily dose to either $0.5 \mathrm{mg}$ daily or to $1 \mathrm{mg}$ daily in three of the cases did not seem to improve cabergoline effectiveness. Whether the increase was performed too soon to be able to judge the added benefit, it is difficult to say based on the currently available data. However, in the only case where we performed a high frequency surveillance of the plasma ACTH after the introduction of cabergoline (case 1), the plasma ACTH decreased from 152 to $57 \mathrm{ng} / \mathrm{L}$ (N 7-63) at 3 days after starting cabergoline. Moreover, the dose most frequently used in the literature was $0.5 \mathrm{mg}$ daily. Therefore, if cabergoline is started at a dose of only $0.25 \mathrm{mg}$ daily, and if the plasma ACTH does not rapidly decrease, we suggest increasing cabergoline to $0.5 \mathrm{mg}$ daily after as rapidly as one week. If the plasma ACTH still does not normalize and cabergoline continues to be well 
tolerated, the dose may be further increased to $1 \mathrm{mg}$ daily after another week. As no reported case was treated with doses greater than $1 \mathrm{mg}$ daily, we would not encourage increasing the dose of cabergoline beyond $1 \mathrm{mg}$ daily. In our series, the increase in the dose of cabergoline was not tolerated because of nausea in one of the patients. Nausea was also experienced in another case (case 5) of the total of nine cases. No other side effects due to cabergoline use were encountered in our series.

Increasing the dose in the case of an escape to cabergoline treatment was described in only one patient in literature (14), and the increase from $0.5 \mathrm{mg}$ to $1 \mathrm{mg}$ daily did not help. Therefore, we are unable to give advice on whether the cabergoline dose should be increased if an escape occurs, but we suggest nevertheless that the maximal dose should not be greater than $1 \mathrm{mg}$ daily.

In conclusion, although based on a limited number of cases and inconsistent results, we feel that the use of cabergoline in the treatment of ectopic or occult CS should be considered a worthwhile treatment option that is well tolerated and enables rapid and sustained control of excess cortisol. We suggest that cabergoline is started at a high dose (0.25-0.5 mg daily) in combination with steroidogenesis inhibitors and that, when the situation allows (and particularly if there is no increase in the plasma ACTH), the steroidogenesis inhibitors are gradually reduced to see whether the obtained effect is partly or entirely due to cabergoline. If plasma ACTH does not rapidly normalize and cabergoline is well tolerated, we suggest increasing the dose of cabergoline to $0.5 \mathrm{mg}$, and then to $1 \mathrm{mg}$ daily at intervals as short as 1 week. Given the rapid effect that we observed in all three cases, we also suggest that the treatment is stopped if no results are seen after 3 months. Larger studies are required given the potential of dopamine receptor agonists to treat ectopic and occult CS.

\section{Declaration of interest}

The authors declare that there is no conflict of interest that could be perceived as prejudicing the impartiality of this case report.

\section{Funding}

This research did not receive any specific grant from any funding agency in the public, commercial or not-for-profit sector. M D I has been supported by the Exchange in Endocrinology Expertise (3E) program of the European Union of Medical Specialists (UEMS), Section and Board of Endocrinology.

\section{Acknowledgments}

The manuscript has been revised for the English by an independent scientific language editing service (Angloscribe).

\section{References}

1 Pozza C, Graziadio C, Giannetta E, Lenzi A \& Isidori AM. Management strategies for aggressive Cushing's syndrome: from macroadenomas to ectopics. Journal of Oncology 20122012 1-9. (https://doi.org/10.1155/2012/685213)

2 Lacroix A, Feelders RA, Stratakis CA \& Nieman LK. Cushing's syndrome. Lancet 2015386 913-927. (https://doi.org/10.1016/ S0140-6736(14)61375-1)

3 Petrossians P, Thonnard AS \& Beckers A. Medical treatment in Cushing's syndrome: dopamine agonists and cabergoline. Neuroendocrinology 201092 (Supplement 1) 116-119. (https://doi. org/10.1159/000317716)

4 Nieman LK, Biller BMK, Findling JW, Murad MH, Newell-Price J, Savage MO \& Tabarin A. Treatment of Cushing's syndrome: an Endocrine Society clinical practice guideline. Journal of Clinical Endocrinology and Metabolism 2015100 2807-2831. (https://doi. org/10.1210/jc.2015-1818)

5 Isidori AM, Kaltsas GA, Pozza C, Frajese V, Newell-Price J, Reznek RH, Jenkins PJ, Monson JP, Grossman AB \& Besser GM. The ectopic adrenocorticotropin syndrome: clinical features, diagnosis, management, and long-term follow-up. Journal of Clinical Endocrinology and Metabolism 200691 371-377. (https://doi. org/10.1210/jc.2005-1542)

6 Ferriere A, Cortet C, Chanson P, Delemer B, Caron P, Chabre O, Reznik Y, Bertherat J, Rohmer V, Briet C et al. Cabergoline for Cushing's disease: a large retrospective multicenter study. European Journal of Endocrinology 2017176 305-314. (https://doi.org/10.1530/EJE-16-0662)

7 Pivonello R, Ferone D, Lombardi G, Colao A, Lamberts SWJ \& Hofland LJ. Novel insights in dopamine receptor physiology. European Journal of Endocrinology 2007156 (Supplement 1) S13-S21. (https://doi.org/10.1530/eje.1.02353)

8 Bertrand A, Marec-Berard P, Raverot G, Trouillas J \& Marabelle A. Cabergoline therapy of paraneoplastic Cushing syndrome in children. Pediatric Blood and Cancer 201055 590-591. (https://doi. org/10.1002/pbc.22581)

9 Bruno OD, Danilowicz K, Manavela M, Mana D \& Rossi MA. Long-term management with octreotide or cabergoline in ectopic corticotropin hypersecretion: case report and literature review. Endocrine Practice 2010 16 829-834. (https://doi.org/10.4158/EP09286.CR)

10 Modica R, Colao A \& Faggiano A. Complete clinical and biochemical control with cabergoline and octreotide in a patient with ectopic ACTH syndrome before surgery. Journal of Endocrinological Investigation 201538 373-374. (https://doi.org/10.1007/s40618-0140221-3)

11 Pivonello R, Ferone D, Lamberts SWJ \& Colao A. Cabergoline plus lanreotide for ectopic Cushing's syndrome. New England Journal of Medicine 2005352 2457-2458. (https://doi.org/10.1056/ NEJM200506093522322)

12 Willhauck MJ, Popperl G, Rachinger W, Giese A, Auernhammer CJ \& Spitzweg C. An unusual case of ectopic ACTH syndrome. Experimental and Clinical Endocrinology and Diabetes 2012120 63-67. (https://doi. org/10.1055/s-0031-1297967)

13 Sakihara S, Kageyama K, Yamagata S, Terui K, Daimon M \& Suda T. A case of ectopic ACTH syndrome treated with intermittent administration of dopamine agonists. Endocrinology, Diabetes and Metabolism Case Reports 2014 140001. (https://doi.org/10.1530/EDM14-0001)

14 Pivonello R, Ferone D, de Herder WW, Faggiano A, Bodei L, de Krijger RR, Lombardi G, Colao A, Lamberts SWJ \& Hofland LJ. Dopamine receptor expression and function in corticotroph ectopic tumors. Journal of Clinical Endocrinology and Metabolism 200792 65-69. (https://doi.org/10.1210/jc.2006-0728)

15 Gatto F \& Hofland LJ. The role of somatostatin and dopamine D2 receptors in endocrine tumors. Endocrine-Related Cancer 201118 R233-R251. (https://doi.org/10.1530/ERC-10-0334) 
16 Grossrubatscher E, Veronese S, Dalino Ciaramella P, Pugliese R, Boniardi M, De Carlis L, Torre M, Ravini M, Gambacorta M \& Loli P. High expression of dopamine receptor subtype 2 in a large series of neuroendocrine tumors. Cancer Biology and Therapy 20087 1970-1978. (https://doi.org/10.4161/cbt.7.12.6957)

17 Francia G, Davì MV, Montresor E, Colato C, Ferdeghini M \& Lo Cascio V. Long-term quiescence of ectopic Cushing's syndrome caused by pulmonary neuroendocrine tumor (typical carcinoid) and tumorlets: spontaneous remission or therapeutic effect of bromocriptine? Journal of Endocrinological Investigation 200629 358-362. (https://doi.org/10.1007/ BF03344109)

18 Reith P, Monnot EA \& Bathija PJ. Prolonged suppression of a corticotropin-producing bronchial carcinoid by oral bromocriptine. Archives of Internal Medicine 1987147 989-991. (https://doi. org/10.1001/archinte.1987.00370050181031)

Received 30 December 2018

Revised version received 12 April 2019

Accepted 1 May 2019 